\title{
Fluïdesa semàntica i variació regional en hidrònims de les comarques valencianes de parla xurra
}

\author{
Antoni Garcia i Osuna \\ Societat d'Onomàstica \\ tonet_osuna@hotmail.com
}

\begin{abstract}
Resum: Amb el present article pretenem exemplificar mitjançant l'estudi dels hidrònims naturals i artificials, tant dels genèrics toponímics com dels pretopònims, de dos dels trets caracteritzadors del lèxic hidronímic: la fluïdesa semàntica -un significat és realitzat mitjançant més d'un significant i, a la vegada, un significant, per més d'un significat. Aquests dos trets caracteritzadors ja havien estat assenyalats per l'investigador nord-americà Thomas Glick tot referint-se a l'estudi del lèxic valencià del reg.

Aquests trets caracteritzadors són referits dins el context de la parla xurra de les comarques valencianes lingüísticament de base castellanoaragonesa. Al si d'aquestes comarques, s'hi estudia el tret de la variació regional, no solament amb diversos resultats lèxics, sinó també formals, fruit del contacte de llengües i de l'adstrat àrab hispànic. A tall d'exemple d'aquests canvis formals, oferim els quatre resultats -hocino/hochino/hogina/ fuchino- corresponents a l'etim llatí FŌCE+ INU, 'gola, congost'.
\end{abstract}

Paraules clau: parla xurra; hidrònims; variació regional; fluïdesa semàntica; adstrat.

Abstract: The purpose of the current article is to exemplify through the study of natural and artificial hydronyms, whether they are generic place-name or preplace-name, two of the characteristic facts of the hydronimic lexicon: the semantic fluency - one signified is built through more than one signifier, and one signifier is built through more than one signified. These two characteristic facts were already mentioned by the north-american investigator Thomas Glick, in reference to the studies of valencian irrigation system lexicon.

These characteristic facts are referred within of the context of the "xurra" speech in valencian regions that have a castilian-aragonese linguistic basis. The fact of the linguistic variations is studied within these regions, with differ- 
ent lexical and formal results due to the language contact and the hispanic-arabian strate. As an exemple of this, it is shown four outcomes - hocino/hochino/ hogina/fuchino - related with the latin etymon FŌCE+ INU, 'gorge, canyon'.

Keywords: "xurra" speech; hydronym; linguistic variation; semantic fluency; strate. 


\section{Motivacions, propòsits i àmbit de l'estudi}

Fem nostra com a títol del nostre estudi la reflexió que encapçala el capítol dedicat al lèxic del reg valencià de l'erudit nord-americà Thomas Glick $^{1}$ perquè des de menut ens va copsar molt el fet que una sola paraula, pozo, servia per denominar coses tant diferents com un bassal al coll d'una muntanya, un aljub o també un gorg al bell mig del barranc; això sí, els tres referents tenien un element de nexe, contenien aigua, per al ramat, per a la boca dels humans o per prendre el bany i aprofitar-la per a les hortes. Per això el camí seguit en aquest estudi ha estat començar per la històrica Vall d'Almonesir com una mena d'epicentre; aquesta vall contenia els llocs moriscos d'Aïr -ara la Vall d'Almonesir-, i l'Algímia, de Matet, amb predomini morisc, i de Pavies, amb només cristians vells; $i$ hem afegit Gaibiel, perquè, no sols per ser ara i adés veïns, sinó perquè fins al segle XVII se la privà de terme propi $\mathrm{i}$ estava enclavada dins la pròpia Vall d'Almonesir però amb senyories diferenciades ${ }^{2}$.

I, com cercles concèntrics, seguint el vell axioma pedagògic que cal anar del conegut al desconegut, anirem exemplificant amb la topo-

1 "El léxico del regadío en el Este de España se caracteriza por dos rasgos distintivos generales: fluidez semántica y variación regional. Muchas veces las definiciones no son precisas y los significados son frecuentemente vagos. Una palabra puede aplicarse a diferentes fenómenos y, a la inversa, una sola cosa puede estar descrita por varias palabras. La variación regional es un corolario lógico de la fluidez semántica: las palabras varían su significado de un sitio a otro."(Glick, 1988: 313).

${ }^{2}$ El cavaller Guerau Iborra testimonia en el procés criminal com a antic procurador del virrei de Nàpols, Ramon de Cardona, que "ni may, ni per ningun temps, lo dit lloch de Gayviel ha tengut terme, ni mollons designats, ni forques y si ni ha hagudes ho ha causat que quan fonch presa la muntanya d'Espadan, estant destroçada la dita Vall d'Almonasir vingué hun procurador que:s deya Vaquedano en lo dit lloch de Gayviel ... e féu forques...i quant tornà a ser procurador lo any mil cinchcents y trenta a ser procurador féu derrocar per dos voltes les [forques de] dit lloch e los mollons de pedres blanques encalçinades que los moros del dit lloch havien fet."( ARV, Reial Audiència, processos criminals, part 2a, caixa 4, núm. 32/ any 1545) (Garcia, 2014).

Dins la vall estricta d'Almonesir, la partició de terme amb els pobles veïns de Gaibiel, Matet, l'Alcúdia de Veo, Aín, Almedíjar, Castellnou, Sogorb i Navaixes va quedar enllestida en 1846; mentre que la Vall i l'Algímia restaren com un sol terme indivís; però, és en 1882 quan comencen els treballs de delimitació d'ambdós termes municipals i no és fins a finals de 1889 quan s'aplega a un acord gràcies a la intervenció del patrici valencià Ciril Amorós; tot i això, puntualment, han renascut topeties i recels fins als nostres dies (Garcia, 2010a). 
nímia de la resta de la comarca de l'Alt Palància i de l'Alt Millars junt a la localitat de l'Alcúdia de Veo que com una rara avis resta situada al vèrtex ponentí de la Plana Baixa; i tot perquè compten amb l'estudi de Natividad Nebot (1991) com a culminació de tot un treball de prop d'una vintena d'articles publicats des de l'any 1981, principalment, a 1'Archivo de Filología Aragonesa, i, més secundàriament, al Boletín del Centro de Estudios del Alto Palancia i al de l'Asamblea de Cronistas Oficiales del Reino de Valencia; i tampoc negligim, de més a més, tot el cabal toponímic contingut al si de la novel·la La marea del tiempo tal com estudiàrem $\mathrm{i}$ assenyalàrem dins del nostre treball "El reboste lingüistic de La marea del tiempo" (Garcia, 2010). La novel·la de Natividad Nebot denota abastament el coneixement directe i afectiu d'aquestes comarques ${ }^{3}$.

El coneixement de la toponímia de les comarques de parla xurra ben possiblement no siga del tot complet però ben cert és que disposem, a més de tot el treball de recerca de Natividad Nebot Calpe, la primera recollida continguda al Corpus Toponímic Valencià- en avant CTV-, els nous materials més arrodonits continguts en els fullets de la col·lecció Toponímia dels pobles valencians(en avant TPV) i les actes, tant de les dues jornades d'Onomàstica promogudes per l'Acadèmia Valenciana de la Llengua -Vila-real i Xèrica- i de les trobades intitulades "Els Altres parlars valencians" promogudes per la Universitat de València i la col·laboració d'ajuntaments com el d'Énguera. Tot aquests reculls ens donen la possibilitat de l'estudi d'una no gens menyspreable quantitat de tot el seu cabal lèxic.

L'àmbit d'estudi com ja férem al treball sobre la zoonímia xurra aplega, a més de les assenyalades, Alt Palància, Alt Millars i l'Alcúdia de Veo, la resta de comarques de parla xurra: La Serranía, les localitats de Gátova i Marines pertanyents a la comarca valencianoparlant del Camp de Túria, El Rincón de Ademuz i la localitat de Sinarcas perta-

\footnotetext{
${ }^{3}$ Un acarament entre els dos reculls existents sobre la toponímia torralbina ens deixa aquestes dades, el $C T V$ presenta un total de 93 topònims, mentre que el que Nebot aplega a la seua Toponímia (1991) és de 186, un nombre que el dobla -no debades, la novel·la ja presenta 108 topònims rurals, però no es tracta d'un recull exhaustiu, clar està! Però degudament contrastats ambdós reculls ens surt un total de 44 topònims que no hi són registrats per Nebot (1991), per tant podríem estar davant d'un potencial de 230 topònims per a un terme de $21,2 \mathrm{~km}^{2}$ de superfície que caldria tenir en compte a l'hora d'enllestir el recull de la col·lecció Toponímia dels pobles valencians que patrocina l'Acadèmia Valenciana de la Llengua (Garcia, 2010).
} 
nyent al Llano de Requena-Utiel ${ }^{4}$. No deixem de banda, doncs, la Hoya de Chiva-Buñol i La Canal de Navarrés situades en un lloc més perifèric respecte de l'epicentre anomenat.

Com assenyalarem més avall en més d'una ocasió, el recull del CTV pateix d'una manca de separació entre els hidrònims de caràcter natural i els que ho són artificials, la qual cosa ens dificulta l'adscripció d'un topònim si no coneixem o visitem el lloc en concret, qüestió que representa un gran esforç físic i de temps. Tampoc els fullets de la col·lecció $T P V$ contenen una simbologia adient per al cas que ens ocupa de la fluïdesa semàntica que pretenem mostrar. Es pot recórrer als fulls del Mapa Topográfico Nacional -en avant MTN-, 1:25000 amb molt més detalls i simbologia però de caràcter selectiu i, de vegades, poc fiable. La guia i mapes de Fuster sobre la Serra Calderona publicats per Tossal, únic publicat sobre l'àmbit geogràfic traçat de les parles xurres és, per a nosaltres, un model a imitar, pel seu caràcter exhaustiu i amb una fiabilitat toponímica que, com veurem, no acaba d'anar paral·lela als reculls del $C T V$; de més a més, cada mapa ve acompanyat d'una simbologia clara que ens permet d'assabentar-nos del referent toponímic ${ }^{5}$.

La guia de la Serra Calderona aplega en dos mapes tota la frontera que es caracteritza com veurem més avant d'un cert grau de permeabilitat; el mapa OEST, aplega el límit lingüístic entre Els Serrans - lcublas, parcialment-, l'Alt Palància -Sacanyet, Xèrica i Sogorb només molt

\footnotetext{
${ }^{4}$ Ja fèiem notar a l'estudi de malnonímia xurra que Sinarcas, malgrat estar adscrit actualment a la comarca del Llano de Requena-Utiel, comptant amb l'estudi de de Palomares (1981), coincideix per raons històriques i lingüístiques amb la comarca dels Serrans(Garcia, 2014).

${ }^{5}$ A tall d'exemple oferim les dades referides a bassals naturals i aljubs de tots dos mapes referits a la Serra de la Calderona tot diferenciant les zones lingüístiques:
}

\begin{tabular}{|c|c|c|c|c|c|c|}
\hline \multirow{2}{*}{$\begin{array}{l}\text { Zona } \\
\text { castellano- } \\
\text { aragonesa }\end{array}$} & $\begin{array}{l}\text { 'balsa } \\
\text { natural' }\end{array}$ & $\begin{array}{c}\text { navajo } \\
22\end{array}$ & & $\begin{array}{c}\text { balsa } \\
7\end{array}$ & $\begin{array}{c}\text { balsilla } \\
1\end{array}$ & \\
\hline & 'algibe' & $\begin{array}{c}\text { navajo } \\
32\end{array}$ & $\begin{array}{c}\text { aljibe } \\
12\end{array}$ & $\begin{array}{c}\text { fuente } \\
3\end{array}$ & $\begin{array}{c}\text { pozo } \\
1\end{array}$ & $\begin{array}{c}\text { pocico } \\
1\end{array}$ \\
\hline \multirow{2}{*}{$\begin{array}{l}\text { Zona valen- } \\
\text { cianoparlant }\end{array}$} & $\begin{array}{l}\text { 'bassa } \\
\text { d'argila' }\end{array}$ & $\begin{array}{c}\text { navaix } \\
1\end{array}$ & $\begin{array}{c}\text { navajo } \\
1\end{array}$ & $\begin{array}{c}\text { bassa } \\
3\end{array}$ & & $\begin{array}{c}\text { toll } \\
1 \\
\end{array}$ \\
\hline & 'aljub' & & $\begin{array}{c}\text { aljub } \\
41\end{array}$ & $\begin{array}{c}\text { clotxa } \\
3\end{array}$ & $\begin{array}{c}\text { pou } \\
1\end{array}$ & $\begin{array}{c}\text { cister- } \\
\text { neta } \\
1\end{array}$ \\
\hline
\end{tabular}


parcialment i Altura-, i Gátova i Marines, localitats adscrites al Camp de Túria, i Casinos, Llíria, Olocau i un fragment menudíssim de la Pobla de Vallbona, totes quatre pertanyents als Camp de Túria; el mapa EST, presenta el límit entre el sud-est d'Altura, Sogorb, Soneja, Sot de Ferrer i la part occidental de Gátova i Marines i les localitats valencianoparlants d'Olocau, Serra i Nàquera, totes tres adscrites al Camp de Túria, i les pertanyents al camp de Morvedre: Algar, Algímia de la Baronia, Torres Torres, Estivella, Albalat dels Tarongers, Segart, Gilet i, més parcialment, Sagunt, Petrés, El Puig i Puçol, aquestes dues últimes pertanyents a l'Horta.

\section{Hidrografia natural: 'basses d'argila'}

Volem començar per exemplificar l'anomenada fluïdesa semàntica centrant-nos en les denominacions que reben els bassals d'aigua de pluja que es formen en petites concavitats del terreny, generalment en els colls de muntanya, aprofitant un sòl argilós que manté durant llarg temps l'aigua; aquesta aigua retinguda ha servit per a abeurar el bestiar i atraure els animals de caça. En els poc més de cent quilòmetres quadrats que conformen els termes municipals de la històrica Vall d'Almonesir -la Vall, l'Algímia, Matet i Pavías-i Gaibiel, atrobem tres apel·latius hidronímics que, amb molt poca distància física, resulten ser sinònims: balsa, balsón i pozo. A la vegada, cadascun d'aquests apellatius designen altres realitats físiques: la bassa de reg, l'aljub i el toll o gorg. Però més avant ja hi tornarem al respecte.

\subsection{Balsa}

L' hidrònim balsa-Balsa de los Cuatro Caminos en el collado on es forma la cruilla dels respectius camins de ferradura a Villamalur, l'Alcúdia de Veo, l'Algímia i Matet- es troba més escadussera i difícil de distingir del seu terme polisèmic a causa de què els reculls toponímics, generalment, no diferencien entre hidrografia natural i hidrografia artificial i cal dilucidar la pertinença segons el context del topònim. D'aquesta manera cal atribuir al camp de la hidrografia natural topònims com ara Balsa del Pinar (Torralba del Pinar), Alto de la Balsa, Barranco del Alto de la Balsa i Puntal de la Balsa de Miguela (Titaguas), Balsa de la Peña de Arriba (Ayora), Balsa del Cerrito Royo (Pedralba), Balsa del 
Collado (El Toro), Balsa del Lobo (Pavías), Cerro de la Balsa (Pina de Moltalgrao), Collado de la Balsa (Chelva), El Llano de la Balsa (Altura), El Rincón de la Balsa i la partida de La Balsa (Sacañet).

Fins i tot, en el quadernet de la TPV corresponent a la localitat de Altura, on sí que es fa aquesta diferenciació, assenyala nou basses totes com artificials, mentre que a la guia de Fuster (2013), tres d'aquestes -Balsa de las Cerveras, Balsa de las Navas i Balsa del Torrejón- es troben cartografiades amb el símbol corresponent a "bassa d'argila/ balsa natural". Com es pot veure al nom de les localitats, balsa, es documenta especialment a les comarques de l'Alt Palància i dels Serrans i, més minsa, a l'Alt Millars. Nebot hi afegeix Balsa (de) la Badina d'Espadilla -aquesta tautologia la tractarem més avant. Dins de l'àmbit valencianoparlant només cal apuntar a tall d'exemple el Coll de la Bassa al capdamunt del canvi de vessants que ens porta des de la Plana a Adzeneta.

\subsection{Balsón}

El Balsón per antonomàsia tot just situat en l'ample coll que separa els termes municipals de Matet i l'Algímia, i per on transcorre "el camino real que suelen utilizar los de Pavias y Higueras para ir a Segorbe (1642)"; tot i això el terme s'empra com apel·latiu amb l'ajuda del diminutiu, balsonico, per a referir-se a una desena llarga de bassals emprats per atraure els porcs senglars o bé per donar algun reg a les oliveres com ara el balsonico de la Retoría, situat a un centenar de metres del Corral de la Retoría de la Vall. Nebot documenta al terme de Gaibiel els Balsón de Margenías, Balsón de Félix, Balsón del Profeta, Balsón de Artola, Balsón de Monzón i Balsón de Gabarra, inexplicablement al $C T V$ no es documenta cap d'ells. El $C T V$ el localitza a l'Alt Millars -Fuentes de Ayódar, Ayódar i Montán, Nebot afegeix Torralba, totes quatre localitats fiten entre elles i conformen el vèrtex sud-est de la comarca-, l'Alt Palància -Algímia, Gaibiel i Matet; Nebot encara documenta Balsón del Prado i Balsón del Narigudo a Torás-; com es pot comprovar, tret de Toràs, totes tres localitats se situen en el vèrtex nord-est de la comarca i fiten amb el vèrtex sud-est de l'Alt Millars conformant una petita àrea lèxica molt significativa, com molt bé anota Nebot (1991: 91) "En el Alto Palancia se usa navajo también como sinónimo de balsón, tanto en la toponímia como en el habla viva"; i, 
més escadusserament, a les comarques dels Serrans -La Yesa i Villar del Arzobispo-, el Racó d'Ademús -La Puebla de San Miguel-, la Vall d'Aiora - Ayora i Zarra-i el Llano de Requena-Utiel -Requena i Villargordo del Cabriel.

\subsection{Pozo}

El tercer hidrònim emprat a l'àrea determinada és pozo, també amb una polisèmia ben marcada; molt a prop de El Balsón i, a la mateixa ratlla del terme de Matet i l'Algímia, atrobem el Pozo de Romero a tocar el corral homònim i, ja dins del terme de l'Algímia, però molt a prop, el Pozo del Sastre, també veí del Corral de Pepe Rulla; més allunyat però, encara dins el terme de l'Algímia i associat al Corral de Navarro i al Corral de las Tartugas, el Pozo del Javielo.

Pel que fa a la seua localització, també, com en el cas de balsa, caldria que als reculls toponímics es fes una diferenciació entre hidrografia natural i artificial. A tall d'exemple, els resultats del buidatge dels quatre fulls del MTN corresponents al full Jérica, 639 amb simbologia adient per al cas, mostren 16 pozos; distribuïts d'aquesta manera: 9, a El Toro; dos, a Barracas; un, a Bejís i a Caudiel; i, tres, a Jérica, un d'ells amb el diminutiu: Pocico de Pante; el nombre total dels navajo amb el mateix símbol, són quatre: Navajo del Pino (Sacañet), El Navajo Ancho (Caudiel), Navajo de Pabilo i Navajo de Albares (Jérica). Com és fàcil de veure, en aquest vèrtex sud-oest de la comarca de l'Alt Palància, s'hi dóna una certa preferència per l'ús de pozo sobre el de navajo. Al CTV, per al recull de El Toro, aplega una balsa, 9 navajos i 14 pozos, un d'ells amb el diminutiu: Pocico de las Periquillas; també es produeix un canvi de genèric en el cas del Navajo de Roquete que al MTN hi apareix com a Pozo de Roqueta.

\subsection{Navajo i altres}

Ja fora de l'àmbit definit, atrobem tres hidrònims més de molt diferent abast i pervivència: navajo ${ }^{6}$, badina i laguna.

\footnotetext{
${ }^{6}$ L'apel-latiu navajo és un derivat del mot nava d'origen preromà de filiació indoeuropea; aquest orònim fa referència a les depressions al si de l'altiplà, per aquesta raó Nebot (1991: 127) el documenta com a nom de partides a Altura, Gàtova, Castellnovo, i, especialment, a l'altiplà interior ponentí, amb cotes superiors als mil metres d'alçada,
} 


\subsubsection{Navajo}

L' hidrònim navajo es troba absent del terme de la històrica Vall d'Almonesir i del de Gaibiel però es constitueix en el complementari comarcal perquè es documenta a tota la resta de l'Alt Palància-Almedíjar, El Toro, Toràs, Altura, Pina de Montalgrao, Sacañet, Bejís, Segorbe, Caudiel, Jérica, Barracas i Soneja-; on, com bé assenyala Nebot (1991: 91), s'empra com apel·latiu. Només afecta a dues localitats, Fuente la Reina i Villanueva de Viver, que conformen el vèrtex sud-oest de l'Alt Millars fitant amb Caudiel i Pina de Montalgrao.

Encara més, l' hidrònim s'escampa pels pobles dels Serrans fronterers de l'Alt Palància-Alcublas, Andilla, La Yesa, Aras de los Olmos i amb la variant navazo, Loriguilla i Chelva i, fora de la comarca a Requena (Llano de Utiel) i Gestalgar (La Foia de Bunyol); l'atrobem també a Vallanca i, amb la variant navatón, a Castielfabib (El Racó d'Ademús); i, finalment, a Sinarcas s'atroba una interessant varietat fonètica, lavajo -Lavajo del Rodenillo i La Cañada de los Lavajos-, motivada per un intercanvi de la consonant nasal dental inicial per una lateral, exemple que ve a engrossir un llistat molt ampli tant del castellà, Lebrija/Nebrija (s. XVI), com del valencià i, a l'inrevés, Ponçanal Polçana, partida d'horta al municipi de Montcada ${ }^{7}$. També al veí Camporrobles (LR-U) la partida de Los Lavajos.

El Toro - Collado de la Nava Seca, Nava del Azor. Fora de la comarca de l'Alt Palància, el CTV el recull als Serrans, a La Yesa-Rocha de la Nava-i Andilla-Corral de la Nava-i al Racó d'Ademús, a Castielfabib molt més representada-Casas de la Nava, Fuente de las Casas de la Nava, Morrita de la Nava i la partida de La Nava.

Si estudiem al detall la seua situació orogràfica -full El Toro del MTN- observem una depressió allargada quasi endorreica amb els punts de referència de fondària 1506 m.s.n.m. al punt més septentrional, 1486 m.s.n.m. al centre i 1487 m.s.n.m. en l'extrem meridional i envoltada del Alto del Tomatero 1605 m.s.n.m., el Puntal de Magaña 1615 m.s.n.m. i la Loma de los Andillanos amb cotes que van des dels 1547 m.s.n.m. als 1566 m.s.n.m. del Puntal de Sabuco; el únics punts de desaigüe hi serien al centre però les aigües haurien de salvar els vora 1490 m.s.n.m. del coll on atrobem el Pozo de Roqueta i el Corral de Francho, i al punt més meridional, també amb la mateixa alçada i, com no podria ser d'una altra manera, allí també s'apleguen el Navajo i el Pozo de los Palos. 7 Tenim documentat el terratinent Ponciano Mateu, civi urbis Valentice (1666) o generoso Valentice habitatori (1670) amb terres localitzades en les partides de la Senda de Borbotó, del Cami de Massarrojos i de la Closa (els límits establits actualment) o que lindaven amb les partides actuals del Camí Fondo o de la Palmera: (1678, AMM. s/sig.) "...in partita dicta lo Cami Fondo, habent confines cum...hereditatis Ponsiani 
Fins i tot, la veu valencianitzada com navaix i navaixo depassa els límits lingüístics i el documentem al terme de Llíria que fita amb els d'Andilla, Alcublas i Altura: El Navaix Obscur, Navaix de Cambrilles i Navaixet de Fetge (tots tres aplegats al CTV); però Fuster (2013) al mapa de Tossal, a més del Navaix Obscur, aplega Navajo (de) Tuto i Navajo del Cabrero, localitzats molt a prop de la ratlla del terme municipal d'Altura. Encara més, el fullet turístic Senders de la Concòrdia de Llíria (2002) ens assabenta de l'existència del Navaix de la Ferradura a la vora de l'antic camí de La Yesa a tocar el terme d'Andilla; i pel que fa al Navajo (de) Tuto, l'anomena Bassa de Tuto. Al respecte, Coromines aplega El Navaixo a les enquestes de 1962 a Llíria-Casinos i afirma que "la situació fronterera fa pensar un manlleu del cast" (1997: Vol. $\mathrm{V}, 447 \mathrm{~b})^{8}$.

Mateu", o "...en la partida de la Palmera que afronten en terres de...Ponsiano Mateu" (1672, AMM, s/sig.)

Per altra part, el canvi de la consonant nasal per la lateral queda immers dins d'un procés més global, el de la debilitat de les consonants implosives dintre d'un camí d'anada i tornada, tant dissimilatori com assimilatori per dilació entre nasal i lateral, tant alveolars com palatals. Vegem-ne més detalladament els exemples:

1.- Acció assimilatòria per dilació, on no cal descartar influències analògiques:

1.1.-lateral-nasal $>$ nasal-nasal

dolçaina $>$ donçaina, onçaina (DCVB)(influència de dansa); alzina, olzina (cognom Olcina) $>$ onzina (DCVB); Roldan $>$ Rondan; llenya $>$ nyenya

1.2.- nasal- lateral $>$ lateral-lateral: nivellar $>$ llivellar $(D C V B)$

2.- Acció dissimilatòria per dilació:

2.1.-lateral-lateral $>$ nasal-lateral: qualsevol $>$ vulg. quansevol; coltell $>$ contell, cognom Contell, molt comú a Montcada; (PULLICELLA $>$ ) *polcella $>$ poncella.

2.2.-nasal-nasal $>$ lateral-nasal; aquesta, és precisament la dissimilació de nasals que completaria el doble procés apuntat: assimilació i dissimilació de nasals i laterals:

Ponciano (>PONTIANUS) $>$ Ponçana $>$ Polçana, on caldria grafiar amb la -ç- per corresponde a la grafia romanç resultant de TY.

${ }^{8}$ Com apel-latiu, Escrig (1851: 599a), l'aplega, com a molts termes particulars motivats pel contacte de llengües entre El Camp de Túria, Los Serranos i l'Alt Palància, al seu diccionari: "Naváix ó xo. Pequeño estanque, ó estanquito para tener recogidas las aguas pluviales." I amb aquesta definició obre la porta de la fluïdesa semàntica de poder referir-se tant a la hidrografia natural com artificial, l'aljub; aquesta és una característica que hem assenyalat respecte del genèrics balsa, balsón i pozo.

$\mathrm{Al}$ respecte del malnom MURGAÑ (Cheste-HB) ja anticipàvem al nostre aplec de zoonímia que aquesta veu és una joia lèxica ben aplegada al diccionari d'Escrig (1857): "Musgány: Musgaño ó musaranya (cuadrúpedo)" (596a) i "Musaranya: Musaraña, por el cuadrúpedo y otras acepciones." (595b). Si bé el DCVB no recull musgany, tampoc ho fa el DECat, tot i que dins de l'article MURCEC (V, 849a9-45) hi ha un comentari 
Per tractar de copsar la vitalitat regional de l'hidrònim navajo i amb quins altres hidrònims viu a la toponímia, hem triat dos reculls toponímics de termes municipals d'extensió considerable i ben representativa, un el del terme municipal d'El Toro $-110 \mathrm{~km}^{2}$ - que ocupa geogràficament el punt més ponentí de l'Alt Palància fitant amb les terres de l'Aragó; i el segon, el d'Altura -129,5 km² - que ocupa l'espai del migdia fitant amb el Camp de Túria. En el cas d'E1 Toro, els resultats els he extret del $C T V$-cal dir que no hi ha una diferenciació entre hidrografia natural i artificial- i els navajo en són 9, mentre que els pozo, 14 -un d'ells amb el diminutiu, Pocico de las Periquillas; l'hidrònim balsa només hi apareix en un topònim: Balsa del Collado i indirectament dóna nom a una partida relacionada, El Balsar. Al MTN tot i la manca d'exhaustivitat, hi apareix només un navajo, Navajo de los Sentos i indirectament dos orònims: Puntal del Navajo Moruno i Alto del Navajo; i, a la vegada, també s'apleguen vuit pozo i un més formant part de l'orònim, Puntal del Pozo Viñas.

En el cas d'Altura, hem fet un buidatge de la guia de Fuster (2013) i els resultats en són radicalment diferents: 31 navajo -molts d'ells ja hi són simbolitzats com a aljub-, front a tres balsa-correctament simbolitzats com d'argila-i un sol pozo, Pocico de Pedro el Gatovero.

interessant: "Dubto molt que hagi existit un cat. murany [edició pòstuma de Lab. 1864, copiada després pere altres diccionaris] almenys amb el sentit de 'mostela'...: es deu tractar d'un malentès del cast. murgaño ratoncillo' [1495]...confús més o menys amb muriac."

Una ullada als diccionaris castellans ens assabenten de musaraña, "Musgaño (mamífero). Por extensión cualquier animal pequeño" (J. Casares, 576b) i del sinònim musgaño, "Mamífero carnicero, pequeño que se alimenta de insectos y arañas." (D.Id., 576c). Tot i que la forma murgaño es la primera documentada [1495], la variant més generalitzada ha estat musgaña/o [1555]; de fet, a principis dels anys noranta hi va cobrar certa celebritat entre els grups de música popular reelaborada un grup castellà anomenat $L a$ Musganya.

El sinònim de mussaranya, mur(g)any/ musgany degué de tenir un ús molt residual i localitzat tal com l' atrobem en la toponímia del terme d'Olocau (Camp de Túria) fitant amb les comarques xurres de l'Alt Palància i els Serrans: el puntal del Musgany; i no l'hem pogut atrobar en altres repertoris toponímics - però sí el recull la guia Tossal, com a puntal de 395 m.s.n.m., El Musgany situat a la mateixa ratlla del terme de Marines i conformant amb El Puntal Roig de 525 m.s.n.m. un estret en l'incipient barranc de Carraixet i la carretera local veïna.

A la nostra base de dades de zoònims xurros apleguem musgañ (Caudiel-AP), murgaño (Fuentes de Ayódar (AM), Titaguas (ES) o el Racó d'Ademús), i fins i tot, murgany (Almedíjar i Viver (AP) i Torralba del Pinar (AM). (Garcia, 2012: 55-56). 
La potència i vitalitat de navajo als pobles del migdia palantí, especialment al d'Altura, hi depassen els límits lingüístics per entrar als termes de Casinos i Llíria com ben bé aplega Escrig al seu diccionari i Joan Coromines a l'Onomasticon Cataloniae?.

\subsubsection{Badina}

Hem deixat per al final de l'apartat de sinonímia l'hidrònim badina ${ }^{10}$; és tracta, doncs, d'un arabisme bâțin amb una presència molt minsa $\mathrm{i}$ amb una opacitat rellevant. El $C T V$ el documenta com a nom de sengles partides de Bejís i Viver; el MTN l'aplega també com a nom d'un corral de bestiar, Corral Badina, a Bejís. Però el més significatiu, pel que respecta a la seua manca de vitalitat, són les tautologies aplegades per Nebot: Balsa la Badina a Espadilla i Balsa Badina a Higueras (1991: 90 i 326) ja que el topònim ha restat totalment fossilitzat i cal remotivar-lo amb l'ajut del seu sinònim en aquestes contrades, balsa, com ha estat explicat adés ${ }^{11}$.

\footnotetext{
${ }^{9}$ Per al cas de l'acarament de resultats amb el recull de Coloma al quadernet d'Altura (2013) de la col·lecció TPV mereixeria un comentari més llarg del que disposem en aquest article; somerament, per una part, Coloma fa una distinció entre hidrografia natural i artificial però la disparitat del nombre de topònims és rellevant. Només aplega un navajo natural, Navajo de la Pedrera, que no hi apareix a la guia de Tossal; mentre que en aquesta hi apareixen cinc naturals i cap d'ells és l'aplegat per Coloma; també hi ha disparitat pel que fa a l' hidrònim balsa, que Coloma aplega 9, totes elles artificials, mentre que la guia aplega tres amb el símbol "d'argila".

També hi ha una notable disparitat entre el recull de Jérica de TPV (Doménech, 2013), on només hi apareix el terme navajo en cinc mencions totes elles sota l'epígraf d'hidrografia artificial. Però una ullada al MTN de Jérica hi podem atrobar perfectament simbolitzats com a hidrografia natural tres pozo-Pozo del Royo Mojón, Pozo Albares i Pocico de Pante - i dos navajo -Navajo Pabilo i Navajo Albares; cap dels cinc hidrònims és aplegat al quadernet de Jérica, tan sols hi apareix com a artificial la Balsa de Pabilo. Tot aquest acarament amb la conseqüent disparitat de resultats ens encamina a la necessitat d'un major rigor i exhaustivitat en l'aplegament de la nostra riquesa toponímica.

${ }^{10}$ Dins de l'àmbit del valencià, el Diccionari Normatiu Valencià l'aplega com a apellatiu amb el mateix significat en la primera accepció, 'clot d'aigua embassada, toll gran' però el $C T V$ confirma el seu minso abast, tan sols dues mencions, Badina de la Torre Marçà a Morella i, com a partida rural, La Badina, a Llucena.

${ }^{11}$ Mantenim dubtes raonables que tant la partida El Bardinal, compartida per Altura i Alcublas com El Bardinal a Llíria tenen com a base 1'hidrònim amb el sufix abundancial, perquè són dues partides orientades al migdia, allunyades d'un paratge ombrívol i humit com suggereix el topònim El Verdinal aplegat al terme veí de Sacañet. Al do-
} 


\subsubsection{Laguna}

El nombre de sinònims no acaba amb aquests quatre hidrònims tractats, balsa-balsón, pozo, navajo i badina, sinó que encara Nebot (1991: 199) crida l'atenció sobre 1' hidrònim laguna; menciona sengles partides a Barracas, Segorbe, Villahermosa del Río i Argelita i el llogaret de La Laguna de Cortes de Arenoso i ens diu a la lletra: "Sólo en Cortes de Arenoso existe en esta partida una gran charca de monte, en los demás lugares no, aunque pudo haberlas en otro tiempo". Ben possiblement ens trobem davant d'un sinònim parcial amb una diferencia marcada pel sema 'gran'. El CTV encara amplia les mencions a d'altres localitats del nostre abast estudiat: Puebla de Arenoso (AM), Villar del Arzobispo (ES), Chelva (ES), Tous (CN) i Sinarcas (PU); a tall d'exemple, reportem els orònims que reforcen l'accepció estudiada: Alto de la Laguna a la Puebla de Arenoso i del Villar del Arzobispo o el Pozo de la Laguna a Sinarcas.

\section{Hidrografia artificial: 'aljub'}

En aquest segon capítol tractarem d'explicar la intersinonímia d'aquests mateixos hidrònims però ara amb una accepció diferent: 'construcció artificial per tal de replegar i conservar les aigües pluvials'; que, tant l'espanyol com el català estàndards, empren algibe i aljub respectivament, fills del mateix ètim àrab, $a l-y u b b$.

\subsection{Balsón, pozo i navajo}

Continuant amb la fluïdesa semàntica tractarem de descriure el cas de què un hidrònim s'aplique a un referent diferent seguint el mateix abast geogràfic. Així veurem com balsón, pozo i navajo -el cas de balsa no-

cument sobre els mollons (Garcia, 2014) hi apareix Xi Item, hun altre molló sobre la rambla y lo prado la Verdín y puja recta línea costa amunt. Res resta del bucòlic prat i aigües múrcies que ens suggereix el topònim la Verdín que encara perviu com a partida repartida entre Higueras i Pavías. Era, junt a l'abeurador de la Font de la Maricalva, el segon punt més important d'abeurada del ramat i calia preservar l'ús comú i els passos per arribar-hi, d'igual manera com veurem amb els corrals més avant. La desforestació, però, ha convertit el LOCUS AMEENUS en un pedreguer de roca nua. Creiem sense més que ha hagut una mena d'encreuament analògic que ha donat lloc al topònim Bardinal i no l'esperat Badinal. 
més s'aplica als espais artificials que acumulen l'aigua del reg- també vénen a designar els aljubs. El fet de mantindre el mateix hidrònim per a referir-se a un nou referent ve donat per un fet lògic d'evolució tècnicoconstructiva dels nostres avantpassats. Els bassals d'argila són reforçats i pujats amb murs de pedra seca i se'ls afegeix una coberta de pedra seca anomenada de falsa cúpula seguint les tècniques constructives de les barraques de pedra en sec anomenades en aquesta contrada casetas de bóveda. Amb aquesta coberta, l'aigua de la pluja es protegia de la possible contaminació i brutícia per part de les salvatgines i se n'evitava l'evaporació.

Així a la històrica Vall d'Almonesir atrobem el Pozo de Miguel de Blay junt a una caseta molt a prop del Collado de Matet i, més allunyat, el Balsón de la Costalata a Gaibiel just a la vora del camí reial de Sogorb; i, una miqueta més avant, el Pozo de la Mojonada o de la Virgen de los Dolores, de notable antiguitat i reconstruit cap a finals dels anys cinquanta, localitzat molt a prop de la ratlla de la Vall amb Navaixes, vora el camí reial de Castellnovo a Gaibiel. També a Gaibiel atrobem el Balsón de Mazulda molt a prop de la ratlla del terme de Jérica. Pel que fa a l'àmbit de navajo, tot seguint la guia de Fuster (2013), a Altura es localitzen cinc navajo naturals front a 26, d'artificials.
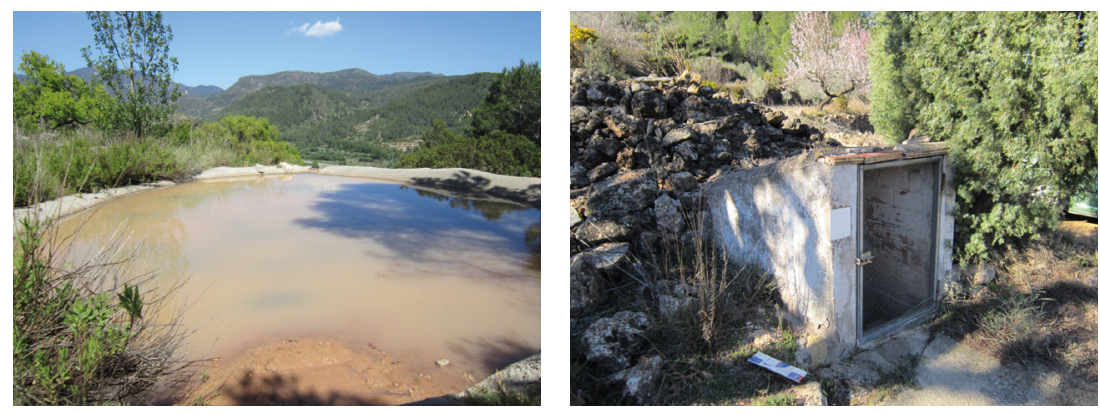

Balsonico de la Re(c)toría (La Vall d'Almonesir) i Balsón de Mazulda (Gaibiel)

\subsection{Aljibe}

El terme aljibe és un terme innovador i estès gràcies a l'escola i, especialment, penetrat junt amb les noves construccions d'aljubs amb volta de canó i rajola que es construïren de la mà dels plans de desenvolupament 
rural de finals dels anys cinquanta junt amb els primers plànols toponímics rurals. Coneguem de primera mà els plànols del Servicio Rural de Castellón corresponents a la Vall d'Almonesir; en concret, al terme de la Vall, es construïren aljubs a les partides de $\operatorname{El~Pra(d)o,~L'Anéjar~i~Za-~}$ galorca i al corresponent mapa van localitzats amb el número 1 corresponent a 'font' i la paraula "aljibe" entre parèntesi. És una veu estranya per a les generacions de gent d'edat i sense vida; a tall d'exemple, hem de dir que en una vetllada amb els germans José i Domingo Granell, $J_{O}$ teras, de l'Algímia al demanar-los pel nom dels topònims es nomenaren els anteriors i al veure la nostra estranyesa, José corregí el genèric amb la paraula notablement alterada: "aljaibe". Tampoc apareix documentat en cap topònim en l'estudi de Nebot sobre la toponímia de l'Alt Millars i de l'Alt Palància i la raó és ben senzilla, Nebot basà el seu corpus toponímic en el buidatge sistemàtic dels fulls 1:50.000 de 1' IGC alguns d'ells com el de Segorbe amb la 1a edició del 1952; una vegada elaborat el recull de cada terme, va recórrer a una segona font, les enquestes, algunes d'elles telefòniques i d'altres -11 municipis d'un total de 51-amb la visita personal al seu terme (1991: 50-51). Per tant Nebot féu un recull més aviat patrimonial allunyat de les veus més innovadores provinents de les tendències uniformadores del règim de la Dictadura franquista. Tampoc Coloma (2013), al seu recull sobre Altura, en documenta cap.

Tot seguint la guia de Fuster (2013) sobre la Serra Calderona, els resultats de l'aplec dels topònims amb els símbol d'aljub de les localitats d'Alcublas (LS), Gátova i Marines (CT) i Altura, Segorbe, Soneja i Sot de Ferrer (AP), són els següents: 32 navajo, 12 aljibe, 3 fuente, 2 pozo -un d'ells, pocico . Amb aquests tres casos, queda clar la pervivència i preeminència de la veu patrimonial navajo sobre la forània aljibe pròpia de l'espanyol estàndard ${ }^{12}$.

El CTV ens documenta l'abast de l' hidrònim a partir d'una data més avançada que el recull de Nebot -la investigadora començà a publicar els seus articles a l'Arxivo de Filología Aragonesa a partir del 1981 i al cap de 10 anys va tenir enllestit el seu darrer gran treball, l'estudi etimològic de la toponímia de les comarques de l'Alt Millars i de l'Alt Palància (1991). De tot arreu de les comarques de parla xurra els resultats de

\footnotetext{
${ }^{12} \mathrm{Pel}$ al cas dels pobles valencianoparlants de la Calderona -Llíria, Olocau, Serra, Nàquera, Algar, Torres Torres, Estivella, Segart, Albalat dels Tarongers, Gilet, Sagunt, Puçol i El Puig-el balanç ha estat el següent: 41 aljub, 3 clotxa -un altre cas de polisèmia-, 1 cisterneta i 1 pou.
} 
les mencions toponímiques no són molt nombroses ni representatives i fan un total de 17 mencions $^{13}$.

\subsection{Aljup}

Però, naturalment, la veu aljub, coincident amb la valenciana, ens resulta molt més interessant lingüísticament. Les mencions toponímiques són molt escasses i notablement desgastades, com veritables fòssils lingüístics.

${ }^{13}$ Per ordre quantitatiu els resultats han estat els següents:

\begin{tabular}{|l|l|l|}
\hline \multicolumn{1}{|c|}{ COMARCA } & \multicolumn{1}{|c|}{ LOCALITAT } & \multicolumn{1}{c|}{ TOPÒNIM } \\
\hline \multirow{5}{*}{ Los Serranos } & Alcublas & Peña del Aljibe \\
\cline { 2 - 3 } & Alpuente & $\begin{array}{l}\text { Aljibe de la Balsa } \\
\text { Aljibe de la Mejina } \\
\text { Aljibe del Pozo de Marin } \\
\text { El Aljibe Herrado }\end{array}$ \\
\cline { 2 - 3 } & Andilla & Casas del Aljibe Viejo \\
\cline { 2 - 3 } & Benagéber & Barranco del Aljibe \\
\cline { 2 - 3 } & Bugarra & $\begin{array}{l}\text { Aljibe de los Cuatro Caminos } \\
\text { Aljibe del Barranco Seco }\end{array}$ \\
\cline { 2 - 3 } & Chulilla & El Aljibe \\
\cline { 2 - 3 } & Villar del Arzobispo & El Aljibe del Campo \\
\hline \multirow{3}{*}{ El Alto Palancia } & Chóvar & $\begin{array}{l}\text { Aljibe de las Majadicas } \\
\text { Puntal del Aljibe }\end{array}$ \\
\hline \multirow{2}{*}{ La Hoya de Buñol } & El Toro & Aljibe de los Vaqueros \\
\hline Llano de Requena-Utiel & Cheste & Aljibe de los Cazadores \\
\hline El Alto Mijares & Gestalgar & Aljibe de las Corchichillas \\
\hline El Rincón de Ademuz & $\varnothing$ & Aljibe de las Herradas \\
\hline La Canal de Navarrés & $\varnothing$ & \\
\hline
\end{tabular}

Fuster (2013) aplega alguns més, degut a què el treball de camp es realitzà entre els anys 2011 i 2013; a Alcublas aplega aljibe de la Chupidilla, aljibe de las Cañadillas, aljibe de los Molinos, aljibe del Colladillo i Aljibe la Seca; a Altura, aljibe Torrejón; a Marines, aljibe de la Romerosa; a Gátova, aljibe de la Pieza Roya, aljibe de los Panizares i aljibe de la Umbría. 
El cim del massís de la Ràpita ha quedat consagrat als mapes oficials com Pico de la Rápita i des d'ací ha passat a totes les guies excursionistes; però, des de l'Algímia estant es diferencia clarament el con final on es localitzen el corral de la Rápita, la Fuente de la Jordana i unes restes de construccions amb calç i arena que suposadament podrien correspondre a les ruïnes arqueològiques de l'ermitori musulmà que dóna nom a tota la partida, del cim que ha rebut tradicionalment dos noms, ara pràcticament oblidats: el Pico (de) Ventura, prenom que correspon a un dels caps de veïns reunits en Consell general del lloc de l'Algímia al 1698, Ventura Balaguer, i que ha generat una dita tòpica molt generalitzada: "Si el Ventura lleva capa, agua segura"; el segon nom ha estat l' Alto l' Ajú i la motivació és molt clara i diàfana, només a uns deu metres del cim (1106 m.s.n.m) hi ha una replaceta plana d'uns deu metres de diàmetre rodada d'un mur de pedra i tota ella amb abundants restes de morter de calç i fragments de teula moruna; tot i que aquest massís de la Ràpita estava creuat longitudinalment de diferents línies de defensa de la Línia Matallana o XYZ, els testimonis orals més antics m'han assabentat que l'aljub ja era una ruïna molt abans dels fets bèl-lics de l'estiu del $1938^{14}$.

La resta de mencions toponímiques i llur distribució comarcal és la següent: Nebot (1991: 305) ha estat la recolectora més important d'aquests fòssils lingüistics, El Jupillo, partida de Cirat i de Villamalur, ambdues localitats de l'Alt Millars; el CTV hi afegeix de Villamalur, el Corral del Jupillo; Collado Jupillo, de Torralba del Pinar també de l'Alt Millars. Nebot recull La Jup a l'Alcúdia de Veo que deu de tractar-se

\footnotetext{
${ }^{14} \mathrm{Al}$ si d'una vetlada amb un dels millors informants de la toponímia algimiana, Domingo Jotera, traguerem a relluir el Gurugú, topònim que coneixia perquè alguns vells del poble de joves havien lluitat a la guerra de l'Àfrica, a més d'anar a Cuba i a las Jelipinas -las fuentes ací són juentes. Hi amanegué el seu fill qui entrà dins la conversació perquè sí que el coneixia i ens contà que als anys vuitanta, l'ajuntament de 1 'Algímia, modèlicament dirigit pel Nelo el Herrero, rebé una subvenció per tal de netejar les sendes i els antics camins de ferradura; hi anaven una colla de set o vuit joves amb Manuel de Bezón, nascut al 1930, que feia de cabocolla. Quan anaven a netejar el camí de Villamalur en direcció al massís de la Ràpita, en resposta a alguna pregunta del veïnat, solia exclamar amb vehemència que "¡nos vamos al Gurugú!. El meu renebot dotat d'una curiositat innata li demanà pel topònim i Manuel de Bezón li explica que així és com els moros de l'exèrcit facciós l'anomenaven. Ben bé no sabé dir-me si era per coneixement directe dels soldats que al 39 arribaren al poble en acabar-se la guerra o perquè ho sentí dir a unes altres persones, ell devia de tindre uns nou o deu anys. El topònim no quallà però encara en restà un lleu record.
} 
sens dubte del mateix Alto del Ajú de l'Algímia, encara viu en persones de molta edat, perquè ambdues localitats comparteixen el mateix cim -als reculls del TPV, tant al fullet de l'Alcúdia (Gil, 2000) com al de l' Algímia(Garcia, 2010a) no hi apareix aquest topònim, tan sols Pico de la Rápita.

Nebot adjunta la partida de La Chupidilla localitzada a Sacañet (AP) tot i que Fuster (2013) a la seua guia la localitza a Alcublas, però a tocar la ratlla del terme de Sacañet; també el $C T V$ la recull amb una variant fonètica, La Chupitilla, ara sí com a partida compartida per Sacañet i Alcublas (ES). El full del MTN de Bejís localitza una Casa de la Chopidilla a Sacañet situada molt a prop de la ratlla del terme amb Alcublas. Fuster (2013) no aplega cap nom de les casetes cartografiades en aquesta partida -només representa una part molt minsa del terme-, però així i tot, encara aporta dos topònims més com una mena de satèl·lits al voltat de la partida de La Chupidilla i situats sobre la ratlla del terme d'ambdues localitats: Aljibe de la Chupidilla-aquesta tautologia ja ens informa abastament sobre la seua fossilització-i, una mica més al nord, conformant un molló trifini, el Mojón de la Chupidilla on fiten Sacañet, Alcublas i Jérica.

El $C T V$ encara ens ofereix una menció allunyada dels dos centres geogràfics atrobats, el vèrtex nord-oriental de l'Alt Palancia - l' Algímia -i l'Alcúdia (vèrtex ponentí de la Plana Baixa)- fitant amb el vèrtex sud-oriental de l'Alt Millars -Villamalur, Torralba del Pinar i més al nord, Cirat-, i el vèrtex sud occidental de l'Alt Palància -Sacañet-amb el vèrtex nord-oriental dels Serrans -Alcublas- poblacions tots elles molt més aïllades i de poc de pes poblacional; es tracta, doncs, del Barranco Juvillo (sic) localitzat al terme de Castielfabib al Racó d'Ademús la qual cosa pot ser un indici d'una major vitalitat ara ja perduda i més encara amb la progressiva entrada de la veu més estàndard, aljibe.

El topònim presenta tres trets fonètics propis de les parles xurres; primerament, l'elisió de la vocal de l'article i la creació d'un fals tall, El Jupillo; aquest fals tall pot arribar a fer canviar el gènere com podem observar en el topònim La Chupitilla partida compartida per Alcublas i Sacañet ${ }^{15}$.

\footnotetext{
${ }^{15}$ Aquest canvi de gènere per la mateix raó l'hem atrobat al recull d'ordenances impreses en castellà al segle XVIII de les sèquies de l'Horta on, molt a sovint, atribueixen el femení, la azud, fins i tot la azuda, en referir-se a l'assut: "XLIV. Los cequieros tienen la obligacion de mondar el trecho que hay desde la azud hasta la almenara que llaman
} 
Pel que fa a la consonant de l'ètim àrab, els topònims atrobats presenten dues solucions: l'aspirada velar [x], en el cas dels topònims localitzats a l' Algímia, Alcúdia, Villamalur, Torralba del Pinar i Cirat, amb l'excepció del barranco Juvillo de Castielfabib; i l'africada/ty/en la Chupidilla de Sacañet i Alcublas molt a prop de la ratlla del terme de Llíria on també la realització fonètica de la veu aljub és amb l'africada [t] per ser una comarca apitxada ${ }^{16}$.

La caiguda de la consonant lateral implosiva provinent de l'article àrab -també documentada al valencià del Camp de Túria on sovint s'ou jup- és molt habitual en l'adaptació dels arabismes com assenyalarem en șaharīğ, en part per l'elisió de la vocal i la formació d'un fals tall que el deixa de banda i també perquè atrobem la caiguda de les consonants líquides en posició implosiva: per no anar més lluny a l'Algímia, la umbría de Ja(r)que. Tret dels casos que porten el diminutiu com a mostra de lexicalització, el Alto l'Ajú(b) mostra un dels fenòmens més característics de la parla xurra, la caiguda de la consonant oclusiva en posició implosiva; podem adduir, al respecte, molt exemples en la toponímia com ara Sacañé i Marmalé ambdós a Gàtova, el municipi de Matet que al seu escut municipal "parlant" llueix davall de les quatre barres una flor de te-naturalment, te de roca-, El Recuén a la Vall d'Almonesir on a més es dóna l'apòcope de la vocal -o final i la caiguda de la oclusiva velar sorda $/ \mathrm{k} /$. Una altra característica és el manteniment de l'oclusiva dental sorda intervocàlica com observem en Chupadilla o Jupillo en totes les mencions tret de Juvillo de Castielfabib ja pertanyent a un indret més allunyat.

El cas de la casa de la Chopidilla té tota la traça de ser una de les errades en la toponímia impresa al mapa del $M T N$; el nostre informant de Sacañet ens diu que desconeix el nom de la casa; només ens assabenta de què aquella contrada estava a més d'una hora en cavalleria del

tandera, [...]" Ordenanzas Acequia de Mestalla, 1771; "XL. [...] que dicho guarda deba cuidar de la azuda ó presa y almenaras, [...]" Ordenanzas Acequia de Mislata, 1751.

${ }^{16}$ Cal fer notar que el terme municipal de Líria és molt extens especialment d'orient a occident fitant septentrionalment amb els pobles de parla xurra com ara Gàtova, Marines (CT), Altura (AP) i Alcublas (ES); de més a més, ha estat la parada final per als ramats transhumants provinents de l'Aragó i un centre mercantil que ha atret els habitants dels Serrans i de les localitats de Sacañet i de les masades d'Altura-Cucalón, Abanillas, Uñoz. Amb tot aquest conjunt de factors s'ha formalitzat una frontera permeable a jutjar pels localismes aplegats al diccionari d'Escrig, un edetà il·lustre, que ben possiblement precisa d'una monografia més aprofundida. 
poble i hi havia moltes casetes per recerar-se; ara, en ruïna la majoria. De ser bona la lliçó, Chopidilla seria resultat d'una remotivació amb el creuament amb l' abundancial de chopo.
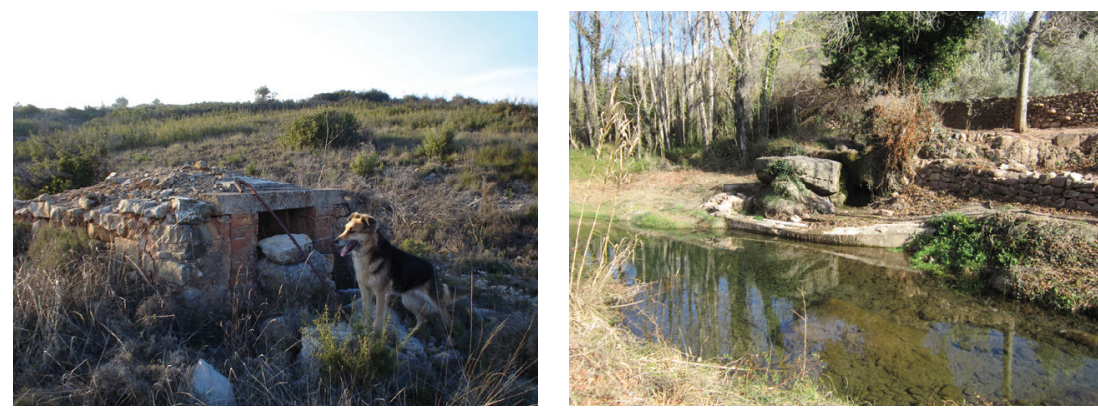

Pozo de la Mojonada (La Vall d'Almonesir) i El Pocico Chorrador (La Vall d'Almonesir)

\section{Hidrografia natural: 'tolls d'aigua al llit d'un corrent d'aigua'}

\subsection{Pozo}

Tot seguint el fil conductor de l'article, caldria dirigir la mirada cap a 1' hidrònim pozo amb una tercera accepció d'acumulació d'aigua en clotades perforades de forma natural en el llit d'un corrent d'aigua. Dins de l'àmbit primigeni de l'estudi atrobem el Pozo de la Gamella a l'Algímia al llit de la Rambla del Baladrar tot just davall del Azud; al llit del Barranco del Marchante, tributari de la Rambla de Algimia, es localitzen tot un rosari de gorgs: l'usat com a piscina de la jovenalla de l'Algímia fins a finals dels anys seixanta era el Pozo Hondo o, senzillament, Pozo del Marchante, tot i que es troba al terme de la Vall; molt a prop del poble de la Vall, atrobem el Pocico Chorrador; precisament, el gorg format en el Río Chico era fruit de l'aigua sobrant del reg que anava a perdre des de la Fuente Larga i queia des d'una certa alçada sobre unes roques ben polides. Abans de bastir-ne la moderna piscina de La Palanca als anys setanta, era on anava la xicalla de la Vall. Ja més avall, en el Río Chico i ja dins del terme de Sogorb, al llogaret de Cárrica, atrobem un bon toll d'aigua anomenat el Pozo de los Gitanos. 
També al Río Regajo al terme de Gaibiel hi ha un rosari de gorgs amb la mateixa finalitat; un dels gorgs de més nomenada era el Pozo de la Eriza on es podien llançar els més atrevits des del pontó que travessava el riu el Camino de Segorbe o de la Costalata. La quantitat de pozo és innumerable $\mathrm{i}$ abasta tot el territori estudiat; però, novament, adoleix d'una mancança que caldria solventar en el moment de realitzar l'enquesta: fer una classificació rigorosa segons les diferents accepcions.

Una mirada a La marea del tiempo ens forneix de la diferenciació de les diferents accepcions: al llit del barranc o de la rambla s'atroben el Pozo, el Pozo Sin Suelo -"decían que su profundidad era tanta como la altura del campanario de Torralba" (Nebot, 1996: 247), pertany al municipi veí de Fuentes i el Pozo del Rac. A la guia de Fuster (2013) s'aplega el Pozo Negro amb el símbol de 'toll/poza' al llit del barranc de Carraixet a Marines Vell.

\subsection{Charco}

Ara caldria fer menció de les diverses variacions sinònimes comarcals i del seu abast i vigència. La veu onomatopeica charco mostra una distribució complementària perquè aplega de sud a nord les comarques de la Canal de Navarrés, on és molt productiva, la Hoya de Buñol i La Serranía, també molt abundant i assenyala, junt a Sinarcas, el límit més septentrional. Els topònims Los Charcos de El Toro i La Charca de Matet, resulten un tant sospitosos perquè no hi són al llit de cap barranc; com tampoc ho són El Charco d'Arañuel i El Charconete de Cirat que tal com ens prevé Nebot (1991: 419) es tracta de sengles lavajos.

\subsection{Tollo}

L'hidrònim tollo, també amb una distribució similar a la de charco, presenta, en canvi, major variació derivativa: 1' abundancial tollagar-Ojal del Tollagar de Villahermosa del Río, l'excepció que confirma la regla exposada perquè se situa al vèrtex més septentrional de la comarca d' El Alto Mijares; Tollico del Conde de Navarrés (CN) i Barranco del Tolluelo de Gestalgar (HB); la resta de topònims mostren un ús com a genèric, v.g. Tollo de la Campana a Millares $(\mathrm{CN})$ o el Tollo de la Zorra a Bicorp $(\mathrm{CN})$ i un reiteratiu ús com especificatiu: Barranco del Tollo (Buñol (HB), Siete Aguas (HB), Chelva (ES) i Pedralba (ES)) i Barran- 
co de los Tollos (Tuéjar (ES)). Cridem l'atenció sobre el Camino de los Tolls a Tous (CN) a tocar la ratlla d'Alzira. També pot prestar-se a una indeguda interpretació quan forma part d'orònims com ara Cerro del Tollo a Chelva i Cerro de los Tollos a Tuéjar.

Voldríem cridar l'atenció sobre l'ús com apel·latiu que hem oït des de la nostra infantesa a l' Algímia: les olives es plegaven i s'estenien a la sala de la casa i quan hi havia un buen tollo, és a dir, una quantitat suficient per fer la parada -la quantitat d'olives que entraven en cada mòlta-, s'ensacaven i es portaven a l'almácera. Però, en canvi, no ha donat nom a cap dels pozo existents a la Vall d' Almonesir.

\subsection{Gorgo i derivats}

En quart 1loc, passem a considerar 1' hidrònim gorgo, 11. GURGUE(M)

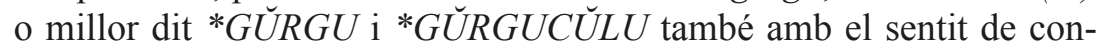
cavitat en el llit d'un riu; només té un ús viu com apel·latiu a la Canal de Navarrés: Gorgo Catalán i Gorgo de la Escalera a Anna, Gorgo de la Cadena a Bolbaite. A la comarca de 1'Alt Millars presenta formes derivades com a nom de partides: El Gorgojo a Ayódar i Espadilla i La Gorgocha a La Puebla de Arenoso. A Calles i Domeño (Els Serrans) s'aplega El Estrecho de Jórgola un mot proparoxíton poc convincent i un seguit de topònims satèllits: Barranco de Jórgola, Fuente de Jórgola i las Casas de Jórgola Alta i Jórgola Baja .

\subsection{Formacions metaforitzants}

I, finalment, deixem tot un seguit d'hidrònims també afectats per la fluïdesa semàntica i nascuts fruit d'un procés metaforitzant que presenten, respecte dels anteriors - pozo, charco, tollo i gorgo- una diferència de grau: el sema de la petitesa.

\subsubsection{Clocha}

El més extens és clocha -11. c. COCHL $\breve{E A}$ però més aviat del 11. v. $C L O C \breve{E} A-$ amb l'accepció de concavitats excavades en la roca del llit d'un barranc per la força impetuosa de l'aigua durant les fortes pluges. L'atrobem usat com a especificatiu dels genèrics barranco -v.g. $B a$ rranco de la Clocha a Tuéjar o de las Clochas a Gaibiel- o vallejo-Va- 
llejo de la Clocha a El Toro; també com apel·latiu-Clochas de Foraña a l'Algímia. Les mencions són abundants a totes les comarques xurres des de l'Alt Millars fins a la Canal de Navarrés, sense oblidar-nos de l'Alt Palància, Els Serrans, Camp de Túria tant a la part xurra -Marines- com a la valenciana on també s'empra com apel·latiu -o el Racó d'Ademús. A la Canal de Navarrés es documenten dos derivacions, el diminutiu Las Clochicas a Chella i una mena de gènere dimensional, Clochón de Rabadán a Énguera i El Clochón a Anna. També cal diferenciar de l'accepció de concavitats a la roca per l'acció de l'erosió del vent com ara la Solana de las Clochas de Fuentes de Ayódar.

\subsubsection{Clote}

La veu preromana clote també ha donat motiu de nominar a concavitats plenes d'aigua com ara el Clote del Regadejo a Teresa o la cèlebre Fuente de los Cloticos a Bejís ${ }^{17}$; res a veure amb l'orònim Clotes de Foraña i Clotes del Collao de Matet d' Algímia que fan referència a foies més reduïdes, però, pel contrari, amb més pendent.

\subsubsection{Cociol, conquete i jarronico}

El recipient per fer la bugada de forma troncocònica ha estat el cociol -val. cossi- que ha nominat el Barranco de los Cocioles d'Alpuente; mentre que la Peña el Cociol de Sacañet fa referència a un orònim que té la forma del recipient al·ludit.

El Estrecho de los Conquetes de Titaguas pren el nom de las concas on es mantenien les brases per calfar-se, el popular brasero. També, de la mateixa manera, el batejador del Barranco de los Jarronicos de Quesa veia aquest recipient en cadascú del pouets del barranc. Nebot refereix un microtopònim, Las Jarras, que eren una mena de pouets sense aigua i amb poca profunditat en Torralba del Pinar per tal d'amagar les collites als agents fiscals de l'època (1991: 331).

També a Énguera atrobem una altre topònim de caire metafòric, el Barranco de las Piletas que veiem ja de forma recta al Abrevadero de

${ }^{17}$ És de tots conegut a l'Horta el cèlebre Clot de la Capelleta o Clot de Fregina al barranc de Carraixet compartit entre Almàssera i Alboraia, on, de l'arqueta del rector, caigueren les formes consagrades del Miracle dels Peixets a les darreries del s. XIV. 
la Pila de Alpuente o la Fuente de la Pileta a Bicorp; també assenyalem una segona accepció en el Puntal de las Piletas al mateix Énguera.

\section{Hidrografia natural: barrancs}

\section{1. (El) Vall}

Iii Item, hun altre terçer molló baix del collado en vista del barranch de la Maricalva [ i del] Lastonar venint recta línea del dit segon molló. Iiii Item, hun altre molló recta línea del dit terçer, junct al camí sobre lo vallet de la Maricalva ${ }^{18}$.

Aquest genèric, el vall, ha esdevingut lema toponímic i, recentment, estudiat pel professor Terrado (2012); el text ens ofereix una mena de sinonímia, barranc-vallet -lo vallet de la Maricalva i, més amunt, barranch de la Maricalva-, amb l'accepció de barranc estret i profund que serveix de canalització de les aigües d'un vessant. Dins de la comarca de l'Alt Palància el terme provinent de VALLIS es manté femení, com podem comprovar en els topònims Barranco, Fuente de la Vall a Gaibiel, a més de la partida el Camino de la Vall o el Camino i Fuente de la Vall a l'Algímia; el poble de la Vall d'Almonesir ha perdut -o ben bé li han tret-1'article a la senyalització de carreteres i a la documentació administrativa, i ja, entre les persones de menys de 60 anys, se sol anomenar Vall; però, en les enquestes resta ben clar, la Vall, la Fuente (de) la Vall. També a Castellnovo Nebot aplegà Valauta que a més de la conservació etimològica del femení testimonia un dels trets mossàrabs com ara la vocalització de la lateral implosiva. Ja fora de l'Alt Palància, atrobem al CTV, La Valbuena i La Valluenga al terme de la Puebla de San Miguel al Racó d'Ademús; La Vallesa a Chiva i Siete Aguas dins la Hoya de Buñol; i també a Énguera, La Vall. Fora de l'àmbit traçat a l'estudi, històricament ha estat La Vall de Cofrentes -la Valle del parlar popular-; i així, també el CTV aplega Las Vallejas a Cortes de Pallás i Las Vallongas a Monforte.

Com a pervivència $i$ aplicació toponímica d'un topònim netament urbà anotem la tautologia del vessant oriental del Barranco de la Maricalva, en el Barranco del Vall ja en terme de Pavías aplegat a la carto-

\footnotetext{
${ }^{18}$ ARV, Reial Audiència, processos, part 1a, lletra S, núm. 4168/ any 1582, f.3v. Estudiat al nostre article del 2014.
} 
grafia del $M T N$ i a la municipal de Pavías, però, malhauradament, negligida al $C T V$, el qual aplega el lema emmascarat dins d'un Barranco de Valdemoro. També atrobem el topònim a Castellnovo, el Vallet-Vallel a l'aplec de Nebot (1991: 292) com a resultat d'un interessant sufix diminutiu -ĚLLU amb apòcope inclòs-i, a Almedíjar, el Vall.

Si considerem que barranco i (el)vall conformen una parella de sinonímia parcial i amb una història lingüística diferent: barranco ha acabat imposant-se per tot arreu i fins i tot ha creat tautologies com ara Rambla del Val i Barranco del Val del Agua a Ademús, Rambla del Val del Agua, Rambla del Val Seco i Barranco de los Valles a Castielfabib, Barranco del Val de Hurón a Pina de Moltalgrao i Barranco de Valdelagua a Aras de los Olmos que denoten la fossilització d'el vall.

\subsection{Reguero}

Però, mentre que el vall ha anat perdent-se, un derivat amb el sufix diminutiu -ICULU>-ejo, ha conformat el genèric vallejo amb un significat apropat a reguero 'barranquet de curt recorregut a la part més alta de les muntanyes': al terme de l'Algímia només s'aplega reguero -Reguero de Eltoro, Reguero del Rincón de la Cima o Reguero del Salto. A la resta de la comarca s'aplega a Benafer i Viver amb una tautologia, Barranco del Reguero; només La Serranía manté una vitalitat compartida per la Vall d'Aiora que amb Sinarcas i Tous encara mantenen viu l'ús com a genèric.

\subsection{Vallejo}

L'hidrònim vallejo té una vitalitat complementària amb reguero $\mathrm{i}$ l'atrobem a Altura, Gàtova, Pina, El Toro i Viver a l'Alt Palància; a Benagéber, La Yesa, Tuéjar, Alpuente i Chulilla als Serrans; Cortes de Arenoso i Villamalur, a l'Alt Millars; Castielfabib i Ademuz al Racó d'Ademús; i, Chiva i Yátova, a la Foia de Bunyol; sense negligir una gran vitalitat també a les poblacions de la Vall d'Aiora i a Sinarcas i, encara, a tota la resta del Llano de Requena-Utiel.

Amb l'adició d'un segon diminutiu atrobem el Barranco del Valejuelo a El Toro (AP), El Vallejuelo a Chelva (ES), El Vallejete a Castielfabib (RA) i El Vallarejo a Chulilla (ES). 


\section{Hidrografia artificial: 'safareig'}

\subsection{Balsa, balsilla i pozo}

Per als receptacles artificials que acumulen l'aigua d'una font, les denominacions més habituals són balsilla, balsa o, fins i tot, pozo tal com atrobem a tall d'exemple als següents topònims: la Fuente de las Balsillas de Vall, La Balsilla d'Altura unida a la font; la Balsa de Cucalón a la vora de la Fuente del Moro d'Altura; i el Pozo de la Fuente de la Sidra a El Toro. Vénen a representar una nova accepció que unim a les ja estudiades.

\subsection{Chariz, jariz i chafaret}

Però la toponímia encara ens depara una grata troballa: els descendents de l'arabisme șaharīg que compta amb els resultats de zafariche (s. X) per a l'espanyol i safareig per a la llengua catalana; també per a l'aragonés, Pardo i Andolz apleguen zafareche.

Nebot (1991:312) aplega la Fuente'l Jariz en El Toro (AP) i El Chafaret, nom d'una partida de Ludiente (AM). El CTV amplia el nombre de mencions amb la partida La Jarica de Cirat (AM) i Fuentes de Ayódar (AM), on també dóna nom al Barranco de la Jarica. Però és la guia de Fuster (2013) la que ens documenta l'ús com genèric al terme d'Alcublas (LS): el Chariz de las Dueñas i el Chariz de la Tejería. Mentrestant, a Cheste (HB) el CTV aplega el mateix resultat que el valencià safareig: El Safareig de Malpic. Tret del topònim de Chest apegat a la zona lingüística del valencià, el que més ens interessa és copsar l'adaptació de la consonant inicial àrab mostrant un doble resultat, la consonant palatal africada/ $\mathrm{t} /$ - chariz- $\mathrm{i}$, per altra banda, la velar aspirada /x/ -jariz- de manera paral·lela als resultats de l'adaptació d'aljub: Chupidilla/ Jupillo ${ }^{19}$.

\footnotetext{
${ }^{19}$ Observant la distribució de l'hidrònim safareig tot al llarg del País Valencià, observem uns resultats minsos que es reparteixen entre Catí (El Maestrat)-Safareig de Pere-; la Ribera Baixa, Corbera -Els Quatre Safaretjos-i Llaurí -El Safaretjot-; a més de testimonis a les comarques meridionals: Planes, Ibi, Xixona i Monòver; i, finalment, hem deixat a part les dues localitats del Camp de Túria, Llíria i la Pobla de Vallbona, les quals fiten amb el terme d'Alcublas: El Safareig i el Cami del Safareig, sengles partides
} 


\section{Hidrografia i oronímia naturals: 'congosts'}

Finalment, tractarem un grup de topònims que ocupen un 1loc gens prototípic perquè tant es poden considerar orònims com hidrònims; són els emprats per denominar el 'pas acongostat per on desemboca una petita vall o un corrent d'aigua' en paraules a la lletra del mestre Coromines (1997: vol. IV, 369b). Les comarques valencianes d'interior són molt agrestes i amb profundes barrancades que faciliten l'existència de molts congosts de vegades minúsculs i familiars. Totes les solucions emprades en la toponímia són resultats d'ètims llatins i els estudiarem segons llur vitalitat.

\subsection{Estrecho}

La veu més extensa als dos territoris lingüístics valencians és el resultat del participi STRICTU, estrecho i ens dibuixa la geografia dels massissos muntanyosos valencians: L'Alt Millars, amb els barrancs tributaris del riu Millars; l'Alt Palància, amb la serra de l'Espadà i el conjunt de muntanyes que davallen des de l'Aragó; El Serrans i el Racó d'Ademús, amb les moles i el canó del riu Túria; Gàtova i Marines, amb els incipients barrancs que conformaran el barranc de Carraixet; les serres de Malacara, Martés i Cabrillas, amb Yátova i el famós río Juanes que davalla per la vora de Bunyol i el massís del Caroig amb el canó del Xúquer a les poblacions de Bicorp i Quesa de la Canal de Navarrés.

El topònim l'atrobem com a nomenador de partida i també com a genèric, en algun que altre cas com a motivador del topònim ja fossilitzat i opac, v.g. El Estrecho de Jórgola (Calles i Domeño); alguns d'aquests estrechos formen part de la geografia excursionista valenciana per llurs atractius naturals com ara el Estrecho del Collado del Cascajar (El Toro) o el Estrecho Chillapájaros (Montanejos).

\subsection{Angosto, gola i derivats, i gorgojo}

Per contra, de l'ètim llatí ANGOSTU, només atrobem dues mencions, la partida d' El Angosto a

rurals ara convertides en urbanitzacions de segona residència, on res resta dels suposats safareigs que donaren nom a les partides. 
Sogorb i el Barranco i partida d'El Angostillo a Cortes de Arenoso.

De l'ètim GULA, atrobem un dels paratges de més atractiu excursionista, la Gola de Lucino al Río Cazuma a Bicorp (CN) i també el topònim nominador de la partida de Las Canteras de Gullirmo o Gullismo a Caudiel(Nebot,1991: 95). De més a més, Nebot assenyala que "en el habla de Arañuel hemos recogido gullirmo, espacio entre dos montañas o peñascos que están muy próximos" (1991: 178). Som davant d'un clar exemple de deformacions profundes -en aquest cas la veu gollizno ja documentada en capbreus de la localitat de Loja (Granada) al 1486 (Martínez, 2002: 272)-i, fins i tot, arbitràries que han sofert les paraules en llur transmissió oral a mida que va obscurint-se llur significat. Una exploració amb cura pels indrets físics ens resulta sumament aclaridora per identificar el perquè dels topònims. El $C T V$ ens assabenta de més mencions que ens dibuixen una distribució més ampla: El Gullizno com a nom de partides de Aras de los Olmos (ES), Ayora(VA), Caudiel (AP) i Requena(LR); Cueva del Gollizno a Chulilla (ES); i, Barranco del Gollizno a Caudiel (AP) i Montán (AM). Cridem l'atenció sobre la correcció de la veu gollizno aplegada al CTV, front a la veu deturpada aplegada al treball de Nebot, gullirmo.

De $G \breve{U} R G U+$ sufix -UCŬLU 'ant. garganta, gola', Nebot cita $E l$ Gorgojo com a partida d'Ayódar i el CTV encara afig el mateix topònim com a partida d'Espadilla, ambdues localitats pertanyents a l'Alt Millars.

\subsection{Resultats de FŌCE+INU}

Hem deixat per al final una de les joies lingüístiques que ens exemplifiquen la variació fonètica, no sols dins d'una comarca, sinó, fins i tot, dins d'una mateixa vall. Ens referim als topònims Hocino/Hochino/ (Loma)Hogina/Fuchino que tenen un idèntic origen etimològic -11. arcaic pop. $F \bar{O} C E$ 'gola'- però que presenten resultats molt alliçonadors que, units als resultats dels arabismes alyubb i șaharīğ més amunt estudiats, ens forneixen d'un coneixement més exacte de l'evolució lingüística d'aquestes terres, especialment, l'Alt Palància, un del nuclis més importants de la permanència dels mudèjars $i$, posteriorment, moriscos a l'antic Regne de València. 


\subsubsection{Hocino}

La veu hocino derivada de $h o z^{20}$-és la més evolucionada i pròpia del castellà i també el topònim més extens tot al llarg de les comarques de l'Alt Palància-Barranco del Hocino (El Toro), Loma del Hocino (Viver) -i dels Serrans-Barranco del Hocino i Fuente del Hocino (Calles), Barranco del Hocino Chelva), El Hocino, Camino i Corral del Hocino(Bugarra), El Hocino i Fuente del Hocino (Alpuente) i El Hocino i Huerta del Hocino (Higueruelas) ${ }^{21}$.

\subsubsection{Hochino}

La veu hochino que atrobem al terme de Viver convivint amb hocinoLoma del Hocino (caldria fer un estudi més aprofundit de la documentació antiga, si n'hi ha per tal d'esbrinar la variació fonètica) formant part dels topònims El Hochino i els seus satèl-lits Camino, Casa i Fuente del Hochino. Per una part presenta l'evolució de la $F$ - inicial, però també un tret mossàrab, el tractament de -CE com palatal africada que al dir de Coromines "és el més general i típics dels parlars mossàrabs" (1997: IV, 370b). Només el terme de Barracas s’interposa entre ambdós termes: Viver i El Toro.

\subsection{3. (loma) Hogina}

Si ens traslladem fins a la Vall d'Almonesir només cal creuar el terme de Jérica i tot just a tocar la ratlla dels termes de la Vall d'Almonesir i Gaibiel atrobem la Loma Hogina que presenta una forma de vuit separada de La Costalata pel Barranco de Salvador. El cercle més al sud del vuit provoca un congost al llit del barranc fet que motivà la

\footnotetext{
${ }^{20}$ Aquesta veu té molta representativitat a la toponímia: nombrosos Barranco de las Hoces a Bugarra, Calles, Castielfabib; de la Hocecilla a Chera, Titaguas, Aras i el Vallejo de las Hocecillas a Alpuente.

${ }^{21}$ La veu es manté molt viva a la veïna Teruel on s'usa com apel·latiu i dóna nom a indrets que tenen una gran projecció excursionista. Presentem a peu de nota l'enllaç amb la pàgina Hoy costra, mañana pus d'excursionisme que ens trasllada al llogaret de Martín del Río del municipi d'Utrillas al bell mig de la comarca de las Cuencas Mineras on podem visitar el hocino del Pajazo, el pozo de las Palomas i el hocino de la Rambla: http://costraypus.blogspot.com.es/2014/01/hocino-del-pajazo-pozo-de-las-palomas-y. html (Accés: 15-I-2015)
} 
nominació amb una adequació del topònim al gènere del genèric. El més interessant pel que fa a la història lingüística és el resultat $-C Y>$ /x/velar aspirada tal com podem observar a l'adaptació d'altres ètims llatins $-v . g$. Jinquer $(<$ *IRCARIU)- i en els dels arabismes estudiats, A(l)ju(b)/Jupillo i Jariz.

\subsubsection{Fuchino}

I, finalment, presentem un quart resultat, El Fuchino compartit pels termes de la Vall i l' Algímia d' Almonesir, és un paratge que denomina un estretament allargat uns tres-cents metres del barranco de Foraña i continua aigües avall ja com a Barranco del Marchante. El topònim està separat de la Loma Hogina -ben mirat i l'experiència de trescar aquestes terres ens assabenta que la partida del Corral de Mayo on pertany la Loma Hogina està a les espatlles de la Vall d'Almonesir i encarada cap al migdia cara a Navajas d' on realment són la majoria dels propietaris de los pedazos - pel cordal de muntanyes que conformen el Alto de la Costalata, el Collado de Gaibiel i el Alto de Santa Bàrbara per als d' Algímia i El Monje Ramos per als de la Vall. És a dir és un indret al bell mig de la vall i ben a recer de la resta de la comarca, potser aquest aillament unit a la població íntegrament morisca ha generat aquest topònim on a més del tancament de la pretònica $\mathrm{O}>u$, es perceben trets fonètics del mossàrab com ara la conservació de la F- inicial, el resultat de Ce, i del llatí en la palatal africada / $\mathrm{g} /$. Hom ha convingut que el resultat fou en mossàrab l'estabilització en l'estat ch del procés evolutiu tot i que Juan Martínez Ruiz afirma que "en realidad no fueron los mozárabes, sino los hispano-árabes, quienes inmovilizaron la $\mathrm{Ce}, i$ en la etapa ĉ" (2002: 190)22.

${ }^{22}$ Coromines, per als resultats de l'ètim $F \bar{O} C E$, aplega el més general la Fou amb mencions localitzades als Ports de Morella-Vallibona-i la Tinença-Bellestar, Bel i la Pobla de Benifassà; també aplega la forma mossàrab viva a la Ribera d'Ebre, la Fotx a Tivissa i Garcia; però assenyala que la palatal africada és la més general i típica dels parlars mossàrabs, en altres valls valencianes ha donat ç, La Foç a Benasal, Xodos, i més meridionals conformant els vèrtexs més occidentals de les comarques de la Vall d'Albaida i la Costera: Aielo [de Malferit], Ontinyent i Montesa -el CTV afig Moixent i Vallada; i encara afig "per consegüent un altre indret del mateix terme, Els Focinos, també deu ser autòcton encara que aquest derivat coincideixi tant amb el castellà hocino" (370b); a continuació entre parèntesi afig les localitats on atrobà el topònim, Montesa i Moixent. El CTV encara ens forneix de més mencions amb una ortografia diferent, 


\section{A tall de comiat}

Passant revista a les unitats lèxiques estudiades al present estudi referides al món de la hidronímia, en primer lloc ens quedem parats per la quantitat, 26 lexies, que denota una inefable riquesa lèxica; algunes d'elles encara vives són emprades com apel·latiu, balsón, pozo, navajo, clocha, reguero, vallejo o estrecho, entre d'altres; al contrari, molt d'elles són veritables fòssils lingüístics que ens informen no sols de la història lingüística, sinó de la història social i quotidiana dels nostres avantpassats, així hem atrobat els descendents dels arabismes $b a$ dina, aljub-ajú, jupillo, chupidilla-o safareig-chafaret, chariz, jariz o tot el conjunt evolutiu derivat de l'ètim F $\bar{O} C E+I N U /-I N A-$ hocino, hochino, fuchino, (loma)hogina.
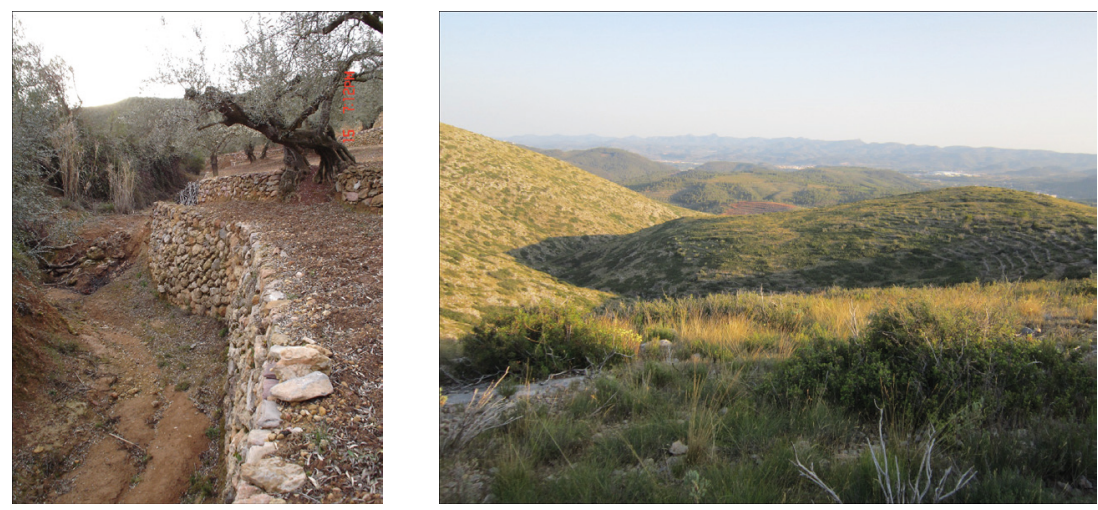

El Fuchino (La Vall i Algímia d'Almonesir) Loma Hogina i el Barranco de Salvador

Per altra part, l'estudi ha cridat l'atenció sobre la necessitat d'una major intensitat i cura en la recollida de la toponímia a jutjar per les disparitats que els diferents reculls tant escrits com cartografiats ens ofereixen. No sols s'ha d'alçar acta exhaustiva dels topònims -"tot està batejat” en les paraules manta vegades oïdes al toponomista Jesús Agut

a més de confirmar la de Moixent: a la comarca septentrional de l'Alcalatén, El Fossino a Vistabella del Maestrat que conviu amb Els Estrets, i Els Fossinos amb el Barranc i Tossal dels Fossinos a Llucena -el nucli septentrional es completa amb La Foç-Cova de la Fos al CTV-a Xodos, Benassal i Vilafranca-; i a la Costera, la Casa i Rambla del Fossino a la Font de la Figuera i la Rambla del Fossino a Moixent. 
Bernat- sinó que cal fer-ne una descripció de l' indret referencial. Tot al llarg de l'estudi hem pogut comprovar aquestes dues característiques, la fluïdesa semàntica i la variació regional, per això cal alçar acta del referent; cosa que, per altra banda, tenim molt fàcil gràcies a les càmeres digitals i la seua localització espacial al mapa topogràfic. Quan es recull el topònim navajo, per exemple, cal assenyalar si es tracta d'una bassa natural -d'argila- o d'una construcció per a la preservació de l'aigua pluvial i així mateix amb tot els genèrics afectats d'aquesta fluïdesa semàntica caracteritzada per una polisèmia en el propi territori. Com diu el títol del llibre de Martínez El lenguaje del suelo (Toponimia) per si de cas hi havia algun dubte, cal fer incursions -les visures d'èpoques pretèrites- a la muntanya $i$ al camp del territori que treballem i tractar d'identificar-ne els noms actuals de molt topònims i contrastar amb fotografies i descripcions dels accidents geogràfics, restes arqueològiques, vegetació i fins i tot la coloració de la terra ${ }^{23}$.

Finalment, voldria regraciar el professor Emili Casanova que allà pels començaments dels anys noranta del segle passat ens convencé de dedicar algun esforç a la toponímia perquè casava molt bé amb aquells que teníem criatures i ens calia d'eixir al camp a passejar-los: beneïda fon la seua ocurrència perquè malgrat conèixer des de menut el terme de l'Algímia, reforçàrem els coneixements del territori amb una activitat molt plaent: totes les vesprades d'estiu, una vegada passat el colp de la calor del migdia, anàvem plegats tota la família a berenar cada dia a un indret diferent. Mentre berenàvem $i$, en les anades i vingudes, anàvem prenent les notes que manta vegades apareixen als nostres estudis, modests però necessaris.

${ }^{23}$ V.g. el Corral de Mayo també s'anomenava -malgrat que molts pocs informants ho saben- el Corral Royo, enclavat al bell mig de la collada que uneix la Loma Hogina amb el Alto de la Costalata, una impressionant mola calcària blanca i grisa, però una exploració de les seues venerables ruïnes, tot i que han estat exposades llarg temps a la intempèrie, encara en alguns angles es pot veure les restes del lluït dels murs amb calç i arena que encara manté la coloració que testimonia l'adjectiu royo, però la lliçó no acaba ací, sinó que també ens forneix de quina percepció es tenia en èpoques pretèrites del color roig, en certa manera, oposat al més intens vermell: les vaques roges dels protocols notarials tenien poc a veure amb el vi vermell. 

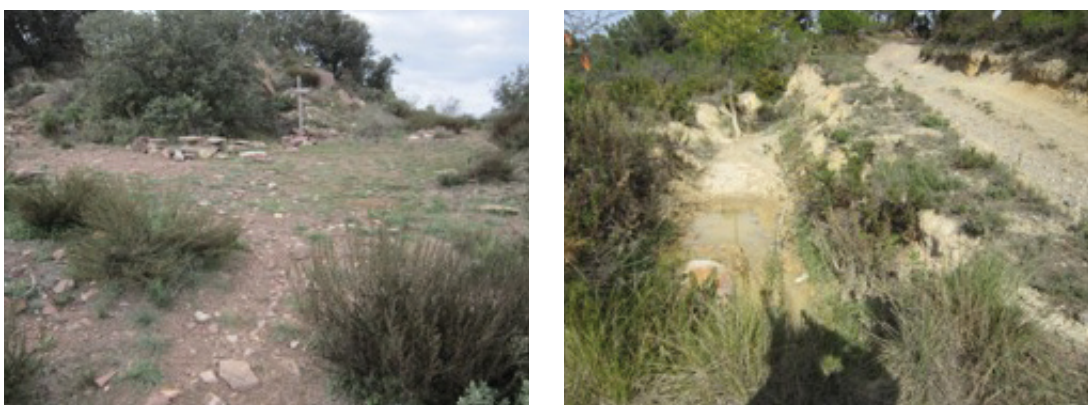

Cim del Alto l'Ajú(p)(l'Algímia i l'Alcúdia de Veo) Balsa de los Cuatro Caminos (Alcúdia-Villamalur-Matet)

\section{Bibliografia}

2002. Llíria. Senders de la Concòrdia. Llíria: Ajuntament de Llíria.

2009. Corpus Toponímic Valencià. València: Acadèmia Valenciana de la Llengua.

2014. Diccionari Normatiu Valencià. València: Acadèmia Valenciana de la Llengua.

Coloma, Xavier. 2013. Toponímia dels Pobles Valencians: Altura. València: Acadèmia Valenciana de la Llengua/Ayuntamiento de Altura.

Coromines, Joan. 1980-1986. Diccionari etimologic i complementari de la llengua catalana. Barcelona: Curial.

Coromines, Joan. 1989-1997. Onomasticon Cataloniae. Barcelona: Curial.

Doménech, J. Ll. \& Millet, J. R. 2013. Toponímia dels Pobles Valencians: Jérica. València: Acadèmia Valenciana de la Llengua/Ayuntamiento de Jérica.

Escrig, Josep. 1851. Diccionario valenciano-castellano. València.

Gil, A.; Gómez, B. \& Palmer, M. 2000. Toponímia dels Pobles Valencians: Alcudia de Veo. València: Generalitat Valenciana/Conselleria de Cultura i Educació.

Garcia, Antoni. 2010a. Toponímia dels Pobles Valencians: Algimia de Almonacid. València: Acadèmia Valenciana de la Llengua/Ayuntamiento de Algimia de Almonacid.

Garcia, Antoni. 2010b. El reboste lingüístic de La marea del tiempo. A Casanova, Emili (ed.) Els altres parlars valencians. València: Denes, 193-228.

Garcia, Antoni. 2011. Malnonímia i els seus graus respecte del recull de malnoms d' Algímia d' Almonesir. A Actes de la IVa Jornada d'Onomàstica. Vila-real 2010. València: Acadèmia Valenciana de la Llengua, 157176. 
Garcia, Antoni. (2012). Els malnoms d'origen animal en les comarques valencianes de parla xurra. A Onomàstica Mediterrània: Onomàstica d'origen zoonímic i dels intercanvis entre pobles. Actes del Convegno di Onomàstica de la Scuola di Dottorato di Torino. València: Denes, 39-64.

Garcia, Antoni. 2014. Consideracions onomàstiques (i històriques) sobre un Memorial dels mollons de 1582 entre les universitats de la vila de Xèrica i la Vall d'Almonesir. A Actes de la VIIa Jornada d'Onomàstica. Jérica 2013. València: Acadèmia Valenciana de la Llengua, 53-69.

Glick, Thomas F. 1988. Regadío y sociedad en la Valencia medieval. València: Del Cenia al Segura.

Guardiola, M. 2013. Toponímia dels Pobles Valencians: Bejís. València: Acadèmia Valenciana de la Llengua/Ayuntamiento de Bejís.

Martínez, Juan. 2002. El lenguaje del suelo (Toponimia). Jaén: Universidad de Jaén.

Nebot, Natividad. 1996. La marea del tiempo. València: Tisbe.

Nebot, Natividad. 1991. Toponimia del Alto Mijares y del Alto Palancia. Estudio etimológico. Castelló de la Plana: Diputació de Castelló.

Terrado, Xavier. 2012. El llatí VALLUM en la toponímia catalana i hispànica. A Miscel-lània d'homenatge a Albert Manent i Segimon-Butlletí Intern de la Societat d'Onomàstica (BISO), núms. 117-118. Barcelona: Societat d'Onomàstica, 451-461.

\section{Cartografia}

1982. Mapa Topográfico Nacional de España, 1:25.000: El Toro (639-I), Viver (639-II), Bejís (639-III, Jérica (639-IV). Madrid: Dirección General dels Instituto Geográfico Nacional.

2002-2003. Mapa Topográfico Nacional de España, 1:25.000: Gaibiel (640-

I), Onda(640-II), Segorbe (640-III, Artana(640-IV). Madrid: Instituto Geográfico Nacional.

Fuster, Pau. 2013. Serra Calderona. Mapes i guia excursionista. València: El Tossal-cartografies. 